\title{
TINGKAT KEPUASAN PENGGUNA RUJUKAN GAWAT DARURAT AMBULANS DESA DI WILAYAH KERJA PUSKESMAS MENGWI 1 TAHUN 2019
}

\author{
I Putu Yoga Kusuma Widnyana*, Ni Made Sri Nopiyani \\ Program Studi Kesehatan Masyarakat Fakultas Kedokteran Universitas Udayana \\ *Email: putuyogakusuma@gmail.com
}

\begin{abstract}
ABSTRAK
Layanan rujukan gawat darurat Ambulans Desa merupakan salah satu layanan yang cukup banyak dimanfaatkan oleh masyarakat di wilayah kerja Puskesmas Mengwi 1 Kabupaten Badung. Namun, hingga saat ini belum pernah dilakukan evaluasi terhadap kepuasan pasien layanan rujukan gawat darurat Ambulans Desa. Penelitian ini bertujuan untuk menilai kepuasan pasien terhadap rujukan gawat darurat Penelitian ini merupakan penelitian cross-sectional deskriptif kuantitatif dengan pengumpulan datanya menggunakan survei kuesioner yang diisi melalui wawancara responden. Sampel dipilih secara consecutive sampling dengan jumlah sampel 75 orang dari 6 desa di wilayah kerja Puskesmas Mengwi 1 Kabupaten Badung. Analisis data yang dilakukan adalah analisis univariat. Penghitungan indeks kepuasan yang dimodifikasi dari Peraturan Menteri Pendayagunaan Aparatur Negara Reformasi Birokrasi nomor 14 tahun 2017. Hasil penelitian ini menunjukkan bahwa secara keseluruhan layanan rujukan gawat darurat Ambulans Desa sudah memuaskan dengan memperoleh nilai Indeks Kepuasan Masyarakat mencapai 3,64 (konversi 91). Kepuasan dari dimensi bukti fisik 3,58 (konversi 89,50), dimensi kehandalan 3,65 (konversi 91,25), dimensi daya tanggap 3,70 (konversi 92,50), dimensi jaminan 3,67 (konversi 91,75), dan dimensi empati 3,64 (konversi 91). Secara umum layanan rujukan gawat Ambulans Desa dinilai sudah memuaskan. Namun, tetap perlu dilakukan monitoring evaluasi kualitas layanan secara berkesinambungan dan peningkatan pada komponen-komponen yang masih dinilai kurang memuaskan.
\end{abstract}

Kata kunci: Kepuasan pasien, rujukan gawat darurat, ambulans desa

ABSTRACT

The Village Ambulance emergency referral service is one of the services that is quite widely utilized by the community in the working area of the Mengwi 1 Badung public health center. There has never been an evaluation of the patient satisfaction of the Village Ambulance emergency referral service. This study aims to assess patient satisfaction emergency referral services. This research is a quantitative descriptive cross-sectional study with data collection using a questionnaire survey filled with interview to respondents. A total of 75 service users was selected with consecutive sampling from 6 villages in the working area of the Mengwi 1 Badung public health center. Data analysis was performed by univariate analysis. The calculation of the satisfaction index refers to and is modified from the Regulation of the Minister of Administrative Reforms Bureaucracy Reform number 14 of 2017. The results of this study indicate that overall the emergency ambulance referral service for the Village has been satisfactory by obtaining a Community Satisfaction Index score 3,64 (convertion 91). Satisfaction from tangible dimension 3,58 (convertion 89.50), reliability dimension 3,65 (convertion 91.25), responsiveness dimension 3,70 (convertion 92.50), assurance dimension 3,67 (convertion 91.75), and empathy dimensions 3,64 (convertion 91). However, monitoring of service quality evaluations still needs to be carried out continuously and improvements to components that are still considered unsatisfactory should be conducted.

Keywords: Patient satisfaction, emergency referral, village ambulance

\section{PENDAHULUAN}

Rencana Pembangunan Jangka

Menengah Daerah Kabupaten Badung (RPJMD) tahun 2016-2021 memiliki dasar penyusunan yaitu terwujudnya kehidupan masyarakat yang berkualitas serta sasaran untuk meningkatnya derajat kesehatan masyarakat dengan pembangunan kesehatan untuk pemantapan akses dan kualitas pelayanan kesehatan dasar dan rujukan. Maka, dirumuskanlah strategi untuk meningkatkan akses pelayanan dan kualitas pelayanan kesehatan dasar dan rujukan yang mengacu kepada Pola Pembangunan Nasional Semesta Berencana (PPNSB) yaitu pembangunan yang dimulai dari daerah pinggiran atau desa dan adanya kebijakan Bupati 
Kabupaten Badung yang dituangkan kedalam Visi dan Misi dalam bentuk Rencana Pembangunan Jangka Menengah Daerah dan Rencana Strategis Dinas Kesehatan maka diperlukan pelayanan kesehatan yang cepat, merata melalui pelayanan Ambulans Desa di semua desa/kelurahan untuk memperkuat sistem rujukan pelayanan kesehatan. (Dinkes Badung, 2016).

Sejak tahun 2016 terdapat 62 ambulans desa yang tersebar di 62 desa/kelurahan se-Kabupaten Badung, beberapa pelayanan yang dilakukan Ambulans Desa berupa kegiatan promotif \& preventif, kunjungan rumah /home care, membantu penanganan kejadian luar biasa (KLB) atau kebencanaan, kegiatan masyarakat yang memerlukan bantuan P3K, membantu Puskesmas dalam melaksanakan pelayanan, serta melakukan kegiatan rujukan berupa rujukan terencana, non-gawat darurat, dan rujukan gawat darurat. (Dinkes Badung, 2018)

Keadaan gawat darurat merupakan keadaan klinis pasien yang membutuhkan tindakan medis segera guna penyelamatan nyawa dan pencegahan kecacatan lebih lanjut (Kemenkes, 2009). Dalam program Ambulans Desa, penanganan keadaan gawat darurat memiliki tujuan untuk meningkatkan angka harapan hidup, menekan angka kematian kasar, serta menurunkan angka kematian ibu dan bayi (AKI \& AKB) (Dinkes Badung, 2016). Berdasarkan data sekunder yang dhimpun oleh tim Ambulans Desa di Dinas Kesehatan Kabupaten Badung sepanjang tahun 2018, rujukan gawat darurat tercatat berjumlah 2017 rujukan yang dihimpun dari 62 Ambulans desa/kelurahan di
Kabupaten Badung. Yang mana angka tertinggi terjadi pada desa-desa/kelurahan yang berada di wilayah kerja Puskesmas Mengwi 1 sebanyak 308 rujukan.

Menurut hasil studi pendahuluan melalui wawancara dengan kepala seksi pelayanan kesehatan rujukan dan kepala bidang pelayanan kesehatan Dinas Kesehatan Kabupaten Badung, sejak dibentuknya program Ambulans Desa pada periode akhir tahun 2016, belum pernah dilakukannya penelitian maupun survei mengenai kepuasan dari pasien yang mendapat layanan-layanan dari Ambulans Desa. Kepuasan pasien merupakan suatu tingkat perasaan pasien yang timbul sebagai akibat dari kinerja layanan yang diperoleh setelah pasien membandingkan dengan apa yang dirasakan. Pasien akan merasa puas apabila kinerja layanan kesehatan yang diharapkan sama atau melebihi harapan. Jadi, kepuasan pengguna layanan/pasien merupakan hal yang penting sebagai respon atau timbal balik dari pelayanan yang telah diberikan (Pohan, 2007). Penelitian terkait di Indonesia pernah dilakukan oleh Hanum et al (2015) di Yogyakarta yang menunjukkan kepuasan $51,7 \%$ responden puas dengan pelayanan perawat Ambulans Yes 118. Penelitian terkait juga pernah dilakukan di luar Indonesia yaitu oleh Jeon et al (2015) di Korea Selatan yang menunjukkan $80 \%$ pasien puas dengan rujukan Ambulans dan oleh Askari et al (2016) di Iran yang menunjukkan $90 \%$ pengguna puas dengan layanan rujukan gawat darurat Ambulans.

Penelitian ini memiliki tujuan untuk mengetahui gambaran tingkat kepuasan pasien pengguna rujukan gawat 
darurat Ambulans Desa Di Wilayah Kerja Puskesmas Mengwi 1 Kabupaten Badung serta gambaran tingkat kepuasan yang ditinjau dari 5 dimensi mutu yaitu bukti fisik (tangible), kehandalan (reliability), daya tanggap (responsiveness), jaminan (assurance), empati (emphaty).

\section{METODE}

Penelitian ini merupakan penelitian cross-sectional deskriptif kuantitatif dengan pengumpulan data menggunakan survei kuesioner melalui wawancara pada pasien pengguna layanan rujukan gawat darurat Ambulans Desa. Penelitian ini dilaksanakan di 6 desa yang berada di wilayah kerja Puskesmas Mengwi 1 Kabupaten Badung Januari hingga Mei 2019. Pengambilan sampel yang digunakan adalah secara consecutive sampling dengan jumlah sampel penelitian sebanyak 75 orang. Menggunakan kuesioner dengan 4 pilihan jawaban skala Likert yaitu 1=Tidak puas, 2=Kurang puas, 3=Cukup puas, 4=Puas. Teknik analisis data yang dilakukan adalah analisis secara univariat dan penghitungan indeks kepuasan yang mengacu dan dimodifikasi dari Peraturan Menteri Pendayagunaan Aparatur Negara Reformasi Birokrasi (PermenPANRB) nomor 14 tahun 2017 sebagai berikut:

$$
\bar{X}=\frac{\mathrm{X}}{\mathrm{n}}
$$

$\bar{X} \quad$ : rata-rata nilai dari masing-masing komponen atau pertanyaan

Penelitian ini telah mendapatkan keterangan kelaikan etik dari Komisi Etik Penelitian (KEP) Fakultas Kedokteran
X : total jumlah nilai masing-masing komponen atau pertanyaan

$\mathrm{N} \quad$ : jumlah responden yang mengisi kuesioner (75 orang)

Kemudian nilai rata-rata pertanyaan atau komponen diatas dijumlahkan serta dirata-ratakan sesuai dengan penglompokan dimensi mutu masing-masing dengan rumus berikut:

$\bar{Y}=\frac{\sum \bar{X}}{\mathrm{p}}$

$\bar{Y} \quad$ : rata-rata nilai setiap dimensi mutu

$\sum \bar{X}$ :jumlah rata-rata nilai setiap komponen atau pertanyaan dalam dimensi mutu

p :jumlah komponen atau pertanyaan yang ada di dalam dimensi mutu

Untuk mendapat nilai rata-rata kepuasan dari keseluruhan dimensi mutu adalah dengan rumus sebagai berikut:

$\mathrm{Nk}=\frac{\sum \bar{Y}}{5}$

Nk : Nilai kepuasan seluruh dimensi mutu

$\sum \bar{Y} \quad$ : total nilai rata-rata pada seluruh dimensi mutu

5 : jumlah dimensi mutu

Agar mendapat nilai internal konversi, maka hasil-hasil penghitungan rumus diatas dikonversikan ke dalam nilai internal konversi dengan menggunakan rumus sebagai berikut:

Nilai Rata-Rata Kepuasan $\times 25$

Universitas Udayana dengan nomor 2019.01.1.0608 tanggal 23 April 2019. 
HASIL

\section{Karakteristik Responden}

Tabel 1. Distribusi Karakteristik Responden Penelitian

\begin{tabular}{|c|c|c|}
\hline Karakteristik Responden & Frekuensi (orang) & Proporsi (\%) \\
\hline \multicolumn{3}{|l|}{ Jenis kelamin } \\
\hline Laki-laki & 34 & 45,33 \\
\hline Perempuan & 41 & 54,67 \\
\hline \multicolumn{3}{|l|}{ Usia } \\
\hline Mean $( \pm \mathrm{SD})$ & $47(13,92)$ & \\
\hline Min - Max & $18-85$ & \\
\hline \multicolumn{3}{|l|}{ Status } \\
\hline Pasien & 35 & 46,67 \\
\hline Pendamping/Keluarga Pasien & 40 & 53,33 \\
\hline \multicolumn{3}{|l|}{ Pendidikan } \\
\hline Tidak bersekolah/tidak tamat SD & 9 & 12,00 \\
\hline SD & 13 & 17,33 \\
\hline SMP & 12 & 16,00 \\
\hline SMA/SMK & 36 & 48,00 \\
\hline Pendidikan Tinggi & 5 & 6,67 \\
\hline \multicolumn{3}{|l|}{ Pekerjaan } \\
\hline Tidak bekerja & 23 & 30,67 \\
\hline Petani & 9 & 12,00 \\
\hline Buruh/Swasta & 30 & 40,00 \\
\hline Wiraswasta & 11 & 14,67 \\
\hline PNS & 1 & 1,33 \\
\hline Guru & 1 & 1,33 \\
\hline \multicolumn{3}{|l|}{ Desa } \\
\hline Baha & 22 & 29,33 \\
\hline Mengwi & 15 & 20,00 \\
\hline Sembung & 14 & 18,67 \\
\hline Gulingan & 13 & 17,33 \\
\hline Kekeran & 9 & 12,00 \\
\hline Sobangan & 2 & 2,67 \\
\hline
\end{tabular}

Tabel 1 menunjukkan responden berjumlah 75 orang terdiri dari 41 orang (54,67\%) berjenis kelamin perempuan dan 34 orang $(45,33 \%)$ berjenis kelamin lakilaki. Untuk usia responden dari 75 orang memiliki rata-rata usia yaitu 47 tahun, usia terendah responden 18 tahun dan usia tertinggi 85 tahun (SD 13,92). Dari status responden, sebesar 40 orang (53,33\%) merupakan pendamping/keluarga pasien dan yang berstatus sebagai pasien sebanyak 35 orang $(46,67 \%)$, dengan pendidikan responden tertinggi adalah SMA/SMK berjumlah sebesar 36 orang $(48 \%)$, dengan pekerjaan responden terbanyak adalah buruh/swasta 30 orang 
(40\%), desa asal responden paling banyak berasal dari desa Baha yaitu sebanyak 22 orang $(29,33 \%)$.

Selain karakteristik responden, dalam penelitian ini juga menghasilkan distribusi waktu pemanfaatan layanan gawat darurat Ambulans Desa (triwulan) serta masalah kesehatan yang dialami pasien. Dengan hasil menunjukkan waktu

\section{Tabel 2. Deskripsi kepuasan responden}

\begin{tabular}{|c|c|c|}
\hline Dimensi & Indeks kepuasan & Konversi \\
\hline $\begin{array}{l}\text { Bukti Fisik } \\
\text { Kondisi ambulans } \\
\text { Kebersihan ambulans } \\
\text { Kenyamanan } \\
\text { Kelengkapan alat } \\
\text { Penampilan petugas }\end{array}$ & 3,58 & 89,50 \\
\hline $\begin{array}{l}\text { Kehandalan } \\
\text { Pertolongan sesuai kebutuhan } \\
\text { Penggunaan alat } \\
\text { Membantu evakuasi } \\
\text { Pemahaman kondisi jalan } \\
\text { Cara mengemudi }\end{array}$ & 3,65 & 91,25 \\
\hline $\begin{array}{l}\text { Daya Tanggap } \\
\text { Mudah dihubungi } \\
\text { Kecepatan ambulans datang } \\
\text { Kecepatan melakukan pertolongan } \\
\text { Waktu tempuh ambulans }\end{array}$ & 3,70 & 92,50 \\
\hline $\begin{array}{l}\text { Jaminan } \\
\text { Kesopanan } \\
\text { Memberikan pertolongan pertama } \\
\text { Rasa aman } \\
\text { Jaminan pelayanan di faskes }\end{array}$ & 3,67 & 91,75 \\
\hline $\begin{array}{l}\text { Empati } \\
\text { Komunikasi dengan pasien } \\
\text { Memberikan pemahaman } \\
\text { Perhatian kepada pasien }\end{array}$ & 3,64 & 91 \\
\hline Rata-rata & 3,64 & 91 \\
\hline
\end{tabular}

Berdasarkan tabel 2 diatas dapat dilihat Indeks kepuasan pasien pengguna layanan rujukan gawat darurat Ambulans Desa memperoleh nilai rata-rata pada 5 pemanfaatan layanan (triwulan) terbanyak yaitu pada bulan-bulan di Triwulan III sebesar $28 \%$, sedangkan masalah kesehatan tertinggi yang dialami oleh pasien layanan gawat darurat Ambulans Desa adalah Hipertensi emergency dengan 12\%.

Kepuasan Pasien Pada Layanan Rujukan Gawat Darurat 


\section{DISKUSI}

Dimensi bukti fisik (tangible) memperoleh nilai 3,58 (konversi 89,5). Hal tersebut sedikit berbeda dengan penelitian yang dilakukan oleh Hanum et al (2018) yang menunjukkan kepuasan pasien pada dimensi bukti fisik sebesar 51,7\%. Namun, penelitian ini sejalan dengan penelitian yang dilakukan oleh Baraz et al (2012) dengan tingkat kepuasan pada ambulans $73,12 \%$, ia juga menyebutkan bahwa peralatan yang tersedia, kebersihan, penampilan ambulans, dan penampilan personel/petugas memiliki hubungan yang signifikan dengan tingkat kepuasan. Dimensi bukti fisik (tangible) yang dari hasil penelitian ini, tidak ada responden yang memberikan jawaban tidak puas dan kurang puas.

Dimensi kehandalan (reliability) dalam penelitian ini meliputi menghasilkan nilai sebesar 3,65 (konversi=91,25). Hasil penelitian ini berbeda dengan penelitian yang dilakukan Hanum et al (2015) kepuasan pada dimensi kehandalan hanya sebesar 44,8\%. Namun, penelitian ini sejalan dengan penelitian yang dilakukan oleh Alshehri et al (2017) di Riyadh yang menunjukkan kepuasan pasien pada dimensi kehandalan adalah $80,6 \%$, dalam penelitiannya juga menghasilkan bahwa perawatan sebelum dirujuk ke fasilitas kesehatan yang diberikan pada pasien membutuhkan pengetahuan dan keterampilan untuk meningkatkan peluang kelangsungan hidup pasien. Dari hasil penelitian ini, masih terdapat responden yang memberikan respon kurang puas pada komponen pertolongan sesuai kebutuhan, penggunaan alat, dan membantu evakuasi.
Dimensi daya tanggap (responsiveness) memperoleh nilai 3,70 (konversi 92,5). Hal tersebut sedikit berbeda dengan penelitian Hanum et al (2015) dimana kepuasan pada dimensi daya tanggap sebesar 48,3\%. Tapi, penelitian ini sejalan dengan penelitian yang dilakukan oleh Peyravi et al (2013) di Shiraz Iran yang menunjukkan kepuasan pasien gawat darurat ambulans pada variabel daya tanggap sebesar 98,9\%. Dari hasil penelitian ini, masih terdapat responden yang memberikan respon kurang puas pada komponen kecepatan ambulans datang dan kecepatan melakukan pertolongan.

Kemudian pada dimensi jaminan (assurance) memperoleh nilai 3,67 (konversi =91,75), hasil penelitian ini sedikit berbeda dengan penelitian sebelumnya yang dilakukan oleh Hanum et al (2015) di Yogyakarta yang menunjukkan kepuasan pada dimensi jaminan (assurance) pelayanan perawat ambulans sebesar 48,3\%. Dari hasil penelitian ini, masih terdapat responden yang memberikan respon kurang puas pada komponen memberikan pertolongan pertama.

Pada dimensi empati (emphaty) memperoleh nilai 3,64 Hasil pada dimensi empati (emphaty) ini sedikit berbeda dengan penelitian Hanum et al (2015) yang menunjukkan kepuasan pasien sebesar $51,7 \%$. Namun, penelitian ini sejalan dengan penelitian yang dilakukan oleh Almasi et al (2016) di Sanandaj, hasilnya kepuasan dari perilaku dan sikap petugas ambulans memiliki nilai hubungan tertinggi diantara parameter kepuasan yang diteliti dengan koefisien korelasi $(0,253)$ dengan harapan pasien. Dari hasil 
penelitian ini, masih terdapat responden yang memberikan respon kurang puas pada komponen perhatian kepada pasien.

Secara keseluruhan, pasien pengguna layanan rujukan gawat darurat Ambulans Desa puas dengan memperoleh nilai Indeks Kepuasan Masyarakat 3,64 (konversi=91). Hal ini serupa dengan penelitian terdahulu oleh Askari et al (2016) yang menunjukkan kepuasan terhadap layanan gawat darurat di daerah Yazd dan Birjand Iran dengan kepuasan pasien sebesar $90 \%$, penelitian oleh Jeon et al (2015) yang menunjukkan $80 \%$ pasien puas serta $83 \%$ keluarga pasien puas dengan lingkungan internal dalam ambulans, serta sedikit berbeda dengan penelitian dilakukan oleh Hanum et al (2015) di Yogyakarta dengan nilai kepuasan umum pasien yaitu $51,7 \%$.

Meskipun telah dinilai memuaskan, terdapat beberapa komponen dalam yang masih dirasa kurang puas oleh responden seperti cara petugas medis dalam menggunakan peralatan, melakukan pertolongan sesuai kebutuhan, petugas yang membantu melakukan evakuasi, kecepatan ambulans datang ke tempat pasien, kecepatan petugas melakukan pertolongan sesuai dengan keadaan pasien cara petugas medis dalam memberikan pertolongan pertama pada pasien sebelum dirujuk, perhatian yang diberikan petugas terhadap keluhan yang dirasakan pasien \& keluarga pasien.

\section{SIMPULAN}

Tingkat kepuasan pasien pengguna rujukan gawat darurat Ambulans Desa secara umum memperoleh indeks kepuasan 3,64 (konversi 91) yang artinya pasien menilai Ambulans Desa telah memberikan pelayanan yang memuaskan dalam melakukan rujukan gawat darurat. Secara khusus pada dimensi bukti fisik (tangible) memperoleh indeks kepuasan 3,58 (konversi 89,5), dimensi kehandalan (reliabilty) memperoleh indeks kepuasan 3,65 (konversi 91,25), dimensi daya tanggap (responsiveness) memperoleh indeks kepuasan 3,70 (konversi 92,5), dimensi jaminan (assurance) memperoleh indeks kepuasan 3,67 (konversi 91,75), dimensi empati (emphaty) memperoleh indeks kepuasan 3,64 (konversi 91).

\section{SARAN}

Pengelola program Ambulans Desa di Dinas Kesehatan Kabupaten Badung diharapkan dapat melakukan kegiatan monitoring dan evaluasi secara rutin berupa survei kepuasan pada masyarakat yang menggunakan layanan-layanan Ambulans Desa. Selain itu, diharapkan pula dapat melaksanakan pelatihan pada petugas Ambulans Desa sebagai upaya peningkatan keterampilan petugas dalam memberikan pertolongan, kesiapsiagaan atau daya tanggap petugas, dan juga keterampilan petugas dalam memberikan perhatian atau empati.

\section{DAFTAR PUSTAKA}

Askari, Roohollah et al (2016). Recipents Satisfaction Of Emergency Medical Service Centers Of Yazd And Birjand: A Cross-Sectional Study. Iran

Almasi, S. Abedi, H. (2016). Study Of The Relationship Between People's Expectatioms From And Their Satisfaction With Emergency Prehospital Services. Sanandaj 
City.Iran: Biol Med (Aligarh). (Vol 8). 327

Alshehri, M. Alotaibi, A. Alanazi, M. (2017). Patient Satisfaction with preHospital Care. Riyadh:International Journal Of Innovative Research In Medical Science. (Vol 02). 1573-1579

Baraz, S. Vardanjani, SaE. Ramezani, M. (2012). Patients Perception And Satisfaction Of The Ambulance Service (115) At Shahrekord Iran. Iran:Life Science Journal 2012;9(4)

Daniel, Johnnie. (2011). Sampling Essentials: Practical Guidelines For Making Sampling Choices. London. SAGE Publications. 101

Dinas Kesehatan Kabupaten Badung. (2016). Rencana Strategis Dinas Kesehatan Kabupaten Badung 20162021. Mangupura, Bali

Dinas Kesehatan Kabupaten Badung. (2018). Laporan Triwulan Ambulans Desa. Mangupura, Bali.

Hanum, Ardani Latifah. Sutono. Setyarini, S. (2015). Tingkat Kepuasan Pasien Terhadap Pelayanan Perawat Ambulans Yes 118 Di Kota Yogyakarta. Yogyakarta.

Jeon, Jinwoo et al. (2015). Satisfaction And Factors Influencing Satisfaction With Internal Environment And Safety Of Emergency Medical Service Ambulances In Korea: Pilot Study Of Patient And Guardians. South Korea
Kementerian Kesehatan RI. (2009). UndangUndang nomor 44 Tahun 2009 tentang Rumah Sakit. Jakarta: Kementerian Kesehatan Republik Indonesia

Menteri Pendayagunaan Aparatur Negara dan Reformasi Birokrasi RI. (2017). Peraturan Menteri Pendayagunaan Aparatur Negara Dan Reformasi Birokrasi Nomor 14 Tahun 2017 Tentang Pedoman Survei Kepuasan Masyarakat Unit Penyelenggara Pelayanan Publik. Jakarta: Kementerian Pendayagunaan Aparatur Negara dan Reforfasi Birokrasi Republik Indonesia.

Parasuraman, A., Berry, Leonard L, and Zeithaml, Valarie A. (1988). SERVQUAL: AMultiple-Item Scale for Measuring Consumer Perceptions of Service Quality. Journal of Retailing. (Vol 64). 12-40.

Pohan, I. S. (2007). Jaminan Mutu Layanan Kesehatan; Dasar-Dasar Pengertian Dan Penerapan. Jakarta: EGC. 